喉頭蓋原発の声門上癌に対する声門上水平部分切除術の治療成績

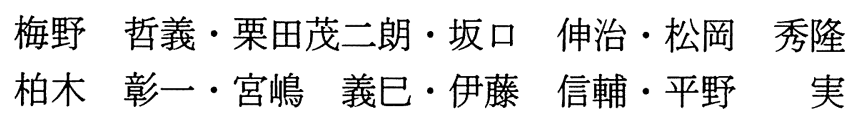

\title{
Supraglottic Horizontal Laryngectomy for Supraglottic Carcinoma
}

-A Retrospective Investigation of 58 Patients -

Tetsuyoshi Umeno, Shigejiro Kurita, Shinji Sakaguchi, Hidetaka Matsuoka, Shoichi Kashiwagi, Yoshimi Miyajima, Shinsuke Ito and Minoru Hirano

(School of Medicine, Kurume University)

A retrospective review of 58 patients of supraglottic carcinoma treated by supraglottic horizontal laryngectomy at Kurume University Hospital between 1971 and 1990 was completed. The following results were obtained:

1. The 3-year primary control rate by supraglottic horizontal laryngectomy was $85 \%$.

2. There was no difference in the 3-year primary control rate between $\mathrm{T} 1$ or $\mathrm{T} 2$ and $\mathrm{T} 3$ or $\mathrm{T} 4$ lesions.

3. The 3- and 5-year cumulative survival rates calculated by Kaplan-Meier method were $82 \%$ and $71 \%$, respectively.

4. Supraglottic horizontal laryngectomy is indicated for $\mathrm{T} 2$ carcinoma, but can be used to treat some T3 or T4 cases.

5. Controlling of neck metastasis is the most important issue in treating supraglottic carcinoma.

Key words : supraglottic horizontal laryngectomy, supraglottic carcinoma, retrospective investigation

はじめに

喉頭蓋原発の声門上癌に対する声門上水平部分切除術 は，音声機能を保存し，癌を根治させる治療法としてす でに確立された術式である122).

久留米大学耳鼻咽喉科学教室では, 1971年以後, 機能 保存手術として声門上水平部分切除術を声門上癌の治療 法の一つとして行ってきた ${ }^{2)}$. 本論文では，喉頭蓋原発 の声門上癌に対する声門上水平部分切除術の治療成績に ついて述べる.

研究対象および方法

対象症例は1971年より1990年の間に，久留米大学耳鼻
咽喉科で治療を行った喉頭癌, 声門上癌184例のうち, 喉頭蓋に原発し，声門上水平部分切除術を初治療として 行った58例である.性別は男46例，女12例で, 年齢は, 46 歳から85歳で平均は, 66歳である。

表 1 に対象症例の TNM 分類 (UICC 1987) を示す. T別内訳は， T1 9 例， T2 36例, T3 9 例, T4 4 例で ある. N別では，N0 46例，N1 8 例，N2 3 例 N3 1 例 であり，全例 M0 である.

\section{治療成績}

1. 原発巣制御率

表 2 亿声門上水平部分切除術の原発巣制御率および再 
表 1 TN 分類 (UICC 1987)

(久留米大学耳鼻咽喉科，1971～1990)

\begin{tabular}{cccccc}
\hline \hline & $\mathrm{N} 0$ & $\mathrm{~N} 1$ & $\mathrm{~N} 2$ & $\mathrm{~N} 3$ & 計 \\
\hline $\mathrm{T} 1$ & 8 & 0 & 0 & 1 & 9 \\
$\mathrm{~T} 2$ & 28 & 5 & 3 & 0 & 36 \\
$\mathrm{~T} 3$ & 7 & 2 & 0 & 0 & 9 \\
$\mathrm{~T} 4$ & 3 & 1 & 0 & 0 & 4 \\
\hline 計 & 46 & 8 & 3 & 1 & 58
\end{tabular}

表 2 声門上水平部分切除術の原発巣制御率および再発率

\begin{tabular}{|c|c|c|}
\hline $\mathrm{T}$ & 3 年原発巣制御率 & 再発率 \\
\hline T1(9) & $88 \%(8)$ & $12 \%(1)$ \\
\hline T 2 (3 6) & $79 \%(29)$ & $21 \%(7)$ \\
\hline T $3(9)$ & $88 \%(8)$ & $12 \%(1)$ \\
\hline T 4 (4) & $100 \%(4)$ & $0 \%(0)$ \\
\hline 計 (5 8) & $85 \%(49)$ & $15 \%(9)$ \\
\hline
\end{tabular}

発率を示す。治療成績は，全例 3 年以上経過した時点で の成績である.

原発巣制御率は, Kaplan-Meier 法に準じて算出して いる.

$\mathrm{T} 19$ 例の 3 年原発巣制御率は, $88 \%$ であり, 再発し た例は 9 例中 1 例であり，その再発率は $12 \%$ である。 T2 36例では， 3 年原発栄制御率は $79 \%$ であり，再発を 来した例は 36 例中 7 例であり，再発率は $21 \%$ である．同 様に T3，T4 の原発巣制御率，再発率は，それぞれ T3
では， $88 \% ， 12 \% ， \mathrm{~T} 4$ では，100\%，0\%である。全 症例 58 例では， 3 年原発巣制御率は $85 \%$ で，その再発率 は15\%である。

\section{2. 原発巣再発例の経過}

表 3 に, 原発巣再発を来した 9 例の経過を示す. 原発 巣再発までの期間は，すべて 4 カ月より 3 年までである.

再発後の 2 次治療は, 喉頭全摘術が 5 例, 放射線治療 が 3 例，咽頭喉頭部分切除術が 1 例である. 2 次治療後, 症例 $2 \sim 9$ は原発巣をコントロールできているが，症例 1 は，前交連より前頸部に浸潤して扣り，喉頭全摘術を 施行しているが，原発巣をコントロールできず， 1 年 8 カ月後に原発巣死している.

原発巣をコントロールできている 8 例のうち, 症例 4 , $5,6,7$ は生存中であるが，症例 $2 ， 3 ， 8$ は，それぞれ 胸椎, 肺, 肺に転移を生じ遠隔死している. 症例 9 は, 4 年10カ月後に食道静脈瘤の破裂で他病死している.

3 ．頸部リンパ節の処置

表 4 に，対象症例58例の患側および健側の頸部に対す る処置拈よびその再発率, 経過中の頸部転移出現率を示 す.

初治療時, 患側頸部郭清術は, N0 例の46例中26例, N1，N2，N3 症例の全例12例計38例に行われている. 患 側の頸部再発率は N0 では，26例中 0 例， $0 \%, \mathrm{~N} 1$ の 9 例中 2 例 $22 \%$ である. N2 の 2 例には，頸部再発は認 めていない. N3 の 1 例は頸部郭清後再発を認めている. な拉，患側頸部再発を来した 3 例のうち $\mathrm{N} 1$ 症例の 1 例 は原発巣再発を認めた例である．患側頸部再発を来した 3 例は, 頸部に対する 2 次治療でもリンパ節再発をコン

表 3 原発巣再発例の経過

\begin{tabular}{|c|c|c|c|c|c|}
\hline & 症例 & 再発時期 & 再発後の二次治療 & $\begin{array}{c}\text { 二次治療後の } \\
\text { 原発巣制御 }\end{array}$ & 転帰 \\
\hline 1 & $\mathrm{~T} 2 \mathrm{~N} 1$ & 1 年 3 カ & 喉頭全摘 & $(-)$ & 原発巣死 ( 1 年 8 カ月) \\
\hline 2 & T $2 \mathrm{NO}$ & 4 カ月 & 喉頭全摘 & $(+)$ & 遠隔死（胸椎）（8 カ月） \\
\hline 3 & T $2 \mathrm{NO}$ & 1 年 2 カ月 & 喉頭全摘 & $(+)$ & 遠隔死（肺）（2 年 8 カ月） \\
\hline 4 & T $3 \mathrm{~N} 0$ & 6 カ月 & 咽喉頭部切 & $(+)$ & 生存 ( 7 年 7 カ月) \\
\hline 5 & $\mathrm{~T} 2 \mathrm{~N} 1$ & 1 年 7 カ月 & 喉頭全摘 & $(+)$ & 生存（ 6 年 1 カ月） \\
\hline 6 & T $2 \mathrm{NO}$ & 1 年 & Ra 60 Gy & $(+)$ & 生存（ 3 年 9 カ月） \\
\hline 7 & T $2 \mathrm{~N} 0$ & 1 年 5 カ月 & 喉頭全摘+Ra $30 \mathrm{~Gy}$ & $(+)$ & 生存（ 3 年 7 カ月） \\
\hline 8 & $\mathrm{~T} 1 \mathrm{NO}$ & 3 年 & Ra 54 Gy & $(+)$ & 遠隔死（肺）（ 3 年 9 力月） \\
\hline 9 & $\mathrm{~T} 2 \mathrm{~N} 1$ & 1 年 7 カ月 & $\begin{array}{c}\text { Ra } 40 \text { Gy } \\
\text { B M C } 4 \text { クール }\end{array}$ & $(+)$ & $\begin{array}{c}\text { 他病死（食道静脈瘤） } \\
\text { ( } 4 \text { 年 } 10 \text { 力月 })\end{array}$ \\
\hline
\end{tabular}


表 4 頸部再発, 転移の頻度

\begin{tabular}{|c|c|c|c|c|}
\hline & $\begin{array}{c}\text { 初治療時 } \\
\text { 頸部郭清 }(+)\end{array}$ & 頸部再発 & $\begin{array}{c}\text { 初治療時 } \\
\text { 頸部郭清(一) }\end{array}$ & 頸部転移 \\
\hline No & 26 & $12 \%(3)$ & 20 & $25 \%$ ( 5 ) \\
\hline N 1 & 9 & $44 \%(4)$ & 0 & - \\
\hline N 2 & 2 & $0 \%(0)$ & 0 & - \\
\hline N 3 & 1 & $100 \%(1)$ & 0 & - \\
\hline 計 & 38 & $21 \%(8)$ & 20 & $25 \%(5)$ \\
\hline
\end{tabular}

トロールできず，腫瘍死している．

$\mathrm{N} 0$ 例 46例中20例には, 初治療時患側頸部郭清術は行 われていない：このうち15例は経過中頸部転移は出現し ていないが，5 例 $25 \%$ に経過中に患側の頸部転移が出現 している. 経過中患側頸部転移が新たに出現した 5 例中 3 例は，頸部郭清術でュントロールしているが，1 例は 頸部郭清術を行ってもコントロールできず，他の 1 例は， 手術拒否し， 2 例ともリンパ節死している.

健側では，全症例の58例中，健側転移を初診時認めた 例は 3 例であり，他の55例には転移は認めていない。こ れらの 3 例は，患側にも転移の認められた N2 のらちの 2 例と，N3の 1 例である. N0 例の 2 例と，患側転移を 認めた 3 例の計 5 例が，健側の頸部郭清術を行われてい るが，これら 5 例には健側の頸部再発は認めていない. 健側 N0 で頸部郭清術を行っていない44例中，4 例，9 \%に，経過中の健側頸部転移出現を認めている．また， N1 例の 9 例は, 健側はすべて頸部転移は初治療時認め ていないが，経過中に 4 例，44\%に，健側頸部転移が出 現している.これら経過中健側頸部転移が新たに出現し た 8 例中， 2 例は頸部郭清術でコントロールできている が経過中他因死し，4 例は頸部郭清術を行ってもコント ロールできず，また 1 例は手術拒否し，リンパ節死して いる。また，他の 1 例は頸部郭清術を行った後，遠隔死 している.

\section{4 . 生存率}

表 5 に対象症例58例の Kaplan-Meier 法による 3 年お よび 5 年累積生存率を示す. 対象58例の 3 年, 5 年累積 生存率は，それぞれ $82 \% ， 71 \%$ ぞある。 T別では，T1 の 3 年， 5 年累積生存率はそれぞれ $89 \% ， 74 \%$ で，T2 では $82 \% ， 74 \%$ である. T3 では， 3 年， 5 年累積生存 率はそれぞれ $71 \% ， 54 \%$ と，T1，T2に比してやや低下 している. T4 の 4 例では, 症例数が少ないが 3 年, 5
表 5 累積生存率

\begin{tabular}{|c|c|c|c|c|}
\hline & & 例数 & $\begin{array}{c}3 \text { 年 } \\
\text { 累積生存率 }\end{array}$ & $\begin{array}{c}5 \text { 年 } \\
\text { 累積生存率 }\end{array}$ \\
\hline $\mathrm{T} 1$ & & 9 & $89 \%$ & $74 \%$ \\
\hline $\mathrm{T} 2$ & & 36 & $82 \%$ & $74 \%$ \\
\hline T 3 & & 9 & $71 \%$ & $54 \%$ \\
\hline T 4 & & 4 & $100 \%$ & $100 \%$ \\
\hline NO & & 46 & $88 \%$ & $74 \%$ \\
\hline N 1 & & 9 & $63 \%$ & $63 \%$ \\
\hline $\mathrm{N} 2$ & & 2 & $100 \%$ & $100 \%$ \\
\hline N 3 & & 1 & $0 \%$ & $0 \%$ \\
\hline \multirow{4}{*}{ Stage } & I & 8 & $100 \%$ & $83 \%$ \\
\hline & II & 28 & $81 \%$ & $70 \%$ \\
\hline & III & 15 & $77 \%$ & $67 \%$ \\
\hline & IV & 7 & $75 \%$ & $75 \%$ \\
\hline 計 & & 58 & $82 \%$ & $71 \%$ \\
\hline
\end{tabular}

年累積生存率ともに $100 \%$ である.

$\mathrm{N}$ 別では， $\mathrm{N} 0$ 例 46 例の 3 年， 5 年累積生存率はそれ ぞれ，88\%，74\%であるが，N1例では，それぞれ，63 $\% ， 63 \%$ と，N0 例より低くなっている．N2 例は症例 数が少ないが， 3 年， 5 年累皟生存率は，ともに $100 \%$ であった. N3 では 3 年生存が得られていない.

STAGE 別では，STAGE I，II，II，N と STAGE が上がるにつれて，3 年， 5 年累積生存率も低下してい る.

5. 死 因

表 6 に，死亡例の死因とその時期を示す，死亡症例数 は29例で，腫瘍死14例，他因死15例である．腫瘍死の内 訳は, 原発巣死が 1 年以上 2 年未満の症例で 1 例で, リ ンパ節死が $1 \sim 2$ 年で 4 例, $2 \sim 3$ 年, $3 \sim 4$ 年, 4 〜 5 年でそれぞれ 1 例, 計 7 例認められる. 遠隔死は, 0 $\sim 1$ 年, $1 \sim 2$ 年, $2 \sim 3$ 年でそれぞれ 1 例, $3 \sim 4$ 年 で 2 例, 計 5 例認められる. 手術死が 1 例認められ，合 併症死，死因不明例は認められない。他病死が計15例認 められるが，その内訳は心筋梗塞 4 例，心不全 3 例，肺 炎 2 例, 脳出血 2 例, 老衰死 2 例, 肺癌 1 例, 食道静脈 瘤破裂 1 例である.

\section{6 . 術後の諸問題}

術中の挿管麻醉のため，手術時気管切開を行う例が多 いが，その閉鎖までの期間を表 7 に示す。術後 30 日以内 の気管口閉鎖が, 12例で, 31 90日の間の閉鎖が13例, 90 
表 6 死 因

\begin{tabular}{|c|c|c|c|c|c|c|c|c|}
\hline \multirow{2}{*}{ 経過年数 } & \multicolumn{6}{|c|}{ 腫瘍死 } & \multirow[t]{2}{*}{ 他因死 } & \multirow{2}{*}{ 計 } \\
\hline & $\mathrm{T}$ & $\mathrm{N}$ & $M$ & 手術死 & 合併症死 & 不明 & & \\
\hline $0 \sim 1$ & 0 & 0 & 1 & 1 & 0 & 0 & 3 & 5 \\
\hline $1 \sim 2$ & 1 & 4 & 1 & 0 & 0 & 0 & 6 & 12 \\
\hline $2 \sim 3$ & 0 & 1 & 1 & 0 & 0 & 0 & 3 & 5 \\
\hline $3 \sim 4$ & 0 & 1 & 2 & 0 & 0 & 0 & 1 & 4 \\
\hline $4 \sim 5$ & 0 & 1 & 0 & 0 & 0 & 0 & 2 & 3 \\
\hline 計 & 1 & 7 & 5 & 1 & 0 & 0 & 15 & 29 \\
\hline
\end{tabular}

表 7 気管口閉鎖までの期間

\begin{tabular}{cc}
\hline \hline 期間 & 症例数 \\
\hline 1 日 0 日内 & 2 \\
$11 \sim 20$ & 5 \\
$21 \sim 30$ & 5 \\
$31 \sim 60$ & 6 \\
$61 \sim 90$ & 7 \\
9 0 日以上 & 16 \\
閉鎖未 & 15 \\
\hline 計 & 56 \\
*Epiglottectomyの 6 名のうち2 名は \\
気管切開を行っていない
\end{tabular}

日以上の閉鎖が16例である．閉鎖に至っていない例が 15 例ある。その理由は，誤嚥が原因のもの，8例，呼吸困 難を生じるため気管口閉鎖ができなかったもの 5 例，気 管口閉鎖前に原発巣再発を来した例が 2 例ある.

表 8 亿声門上水平部分切除術後, 経口摄取開始までの 期間を示す。

術後 10 日以内での経口摄取が44例であり，11日以上 20 日までの間が 7 例， 21 日以上が 1 例認められた。な报， 経口摂取に至っていない例が 6 例認められる. 経口摂取 に至っていない理由は, 誤嚥が原因のもの 5 例, 経口摂

表 8 経口摂取開始までの期間

\begin{tabular}{cc}
\hline \hline 期間 & 症例数 \\
\hline 1 日以内 & 44 \\
$11 \sim 20$ & 7 \\
21 日以上 & 1 \\
未経口摂取 & 6 \\
\hline 計 & 58
\end{tabular}

取前に手術死した例が 1 例ある.

\section{考察}

声門上水平部分切除術の主な適応は，声門上癌で声帯 に可動性のある例である. 久留米大学耳鼻咽喉科学教室 では，1971年以来，声門上水平部分切除術を，声門上癌 の治療法の 1つとして行ってきた2)。また，1984年以後 は, 喉頭全摘出術による摘出喉頭の, 大切片連続段階標 本の病理組織学的研究344) をととに, 声帯の可動性のな い, 一部 T3 症例にも声門上水平部分切除術の適応を行 ってきた．本論文では頭頸部癌に対する機能保存手術5) の一環として, 今回久留米大学耳鼻咽喉科学教室で行っ た 20 年間の声門上水平部分切除術の治療成績を報告した. 以後若干の考察を加える.

\section{1. 原発巣制御率}

全症例58例の声門上水平部分切除術の 3 年原発巣制御 率は，85\%でいまだ満足できる結果ではなかった．T別 の内訳では $\mathrm{T} 1, \mathrm{~T} 2, \mathrm{~T} 3$ ともその原発巣制御率に差は認 められなかった，T4は，声門上水平部分切除術の適応 ではないが，声帯の可動性があり披裂喉頭蓋ひだより一 部下咽頭に浸潤していた例，あるいは一部舌根部に進展 していた $\mathrm{T} 4$ に対しても声門上水平部分切除術を施行し た例が認められた，症例数が少ないが，これらのT4で は，声門上水平部分切除術の原発巣制御率は，100\%で あった. 声門上癌の声帯固定例の病理組織学的研究より Kurita $5^{3 / 4)}$ は, 声門上癌の声帯固定は, 披裂部上の癌 の病変の程度が最も関係し, 甲状披裂筋への癌の浸潤に よる固定例は少ないことを報告している．これらの結果 より，声門上癌に対する声門上水平部分切除術の適応は， 声帯の可動性がある T2 症例が主な適応であるが，T3， $\mathrm{T} 4$ の症例の一部も適応となる症例があり，喉頭全摘術 
を行わず，癌を根治させることができる例がある．

2. 生存率について

全症例の 3 年， 5 年累積生存率は，それぞれ $82 \% ， 71$ \%であり，満足できる結果ではないが，小野ら677)の声 門上癌の治療成績と比較して悪くなかった。

T別の生存率では，T1，T2 の 5 年累積生存率がとも に $74 \%$ に対して，T3で54\%と低くなっていた。しかし， 生存率に大きく関係しているのは頸部リンパ節の状況で あり，原発巣制御率の差は認めなかった．初診時 $\mathrm{N}(-)$ 例と $\mathrm{N}(+)$ 例では, 生存率に差が認められている。 $\mathrm{T}$ とNを考慮したSTAGE 別生存率では, STAGE I，II， III と STAGE が上がるにつれて 3 年, 5 年生存率とも 低くなっている. 原発巣制御率の結果と総合し, 声門上 水平部分切除術の治療成績をさらに向上させるためには, 声門上癌の治療に共通寸る問題である頸部リンパ節転移 の制御が最も重要である.

3. 死因について

腫瘍死は全体で14例にみられたが，原発巣死，手術死 が 1 例ずつに対しリンパ節死が 7 例, 遠隔死が 5 例と多 かった。この結果からも，治療成績の向上には，頸部リ ンパ節の制御が重要である。また，今後遠隔転移の予防， その治療が課題である。

\section{むすび}

1971年より1990年の間に, 久留米大学耳鼻咽喉科にお いて，喉頭蓋を原発とする声門上癌58例に対して行った 声門上水平部分切除術の治療成績を報告し, 以下の結果 を得た。

1. 声門上水平部分切除術の 3 年原発巣制御率は, 85 \%であった。
2. その原発巣制御率は，T1，T2 だけでなく $\mathrm{T} 3, \mathrm{~T}$ 4 でも T別の差は認められなかった.

3 . 全症例の 3 年， 5 年累積生存率は，それぞれ $82 \%$, 71\%であった。

4. 声門上水平部分切除術の適応は, 声帯の可動性が あるT2 が主な適応であるが，声帯に浸潤していない T3の一部，また，T4の一部にも適応となる症例があ る.

5 . 治療成績の向上には，頸部リンパ節転移の制御が 最も重要である.

\section{参考文献}

1 ) Ogura JH, Marks JE, Freeman RB, et al : Result of conservation for cancers of the supraglottics and piriform sinus. Laryngoscope $90: 591 \sim 600,1980$.

2 ) Kawasaki H, Mihashi K, Hirano M, et al : Carcinoma of the larynx; a retrospective investigation of 252 pts. Kurume Med J 29 : 113 128, 1982.

3 ) Kurita S, Hirano M, Matsuoka $H$, et al : A histopathological study of carcinoma of the larynx. Auris Nasus Larynx $12: 172 \sim 177,1985$.

4) 立石守夫 : 大切片標本による声門上癌の病理組織学的研究. 耳鼻 $34:$ 907 917, 1988.

5 ）平野 実, 大久保洋, 栗田茂二朗, 他：頭頸部癌縮小手術 の評価. 癌と化学療法 15(4): 881 886, 1988.

6 ）小野 勇, 海老原敏, 斎藤裕夫, 他: 嗼頭がん症例の長期 追跡調査. 日気食会報 $32: 1 \sim 5 ， 1981$.

7 ）近藤 隆, 河辺義孝 : 喉頭癌長期観察例の検討. 日気食会 報 $32: 279 \sim 286,1981$.

$$
\left(\begin{array}{l}
\text { 別刷請求先 : 梅野哲義 } \\
\text { 个 } 830 \text { 久留米市旭町 } 67 \\
\text { 久留米大学医学部耳鼻咽喉科学教室 }
\end{array}\right)
$$

